\author{
JERZY BIELUK ${ }^{1}$
}

\title{
O potrzebie wprowadzenia do prawa polskiego pojęcia przedsiębiorstwa rolnego
}

\section{Zagadnienia wstępne}

Działalność w zakresie produkcji rolnej może być prowadzona w różnej formie prawnej - jako działalność osoby fizycznej, osoby prawnej, jednostki organizacyjnej nie posiadającej osobowości prawnej. Działalność taka prowadzona jest w ramach określonej całości organizacyjnej, którą możemy określić jako rolniczą jednostkę wytwórczą (bądź jednostkę produkcyjną). W prawie polskim występują dwa legalne pojęcia zorganizowanych jednostek produkcyjnych - gospodarstwo rolne i przedsiębiorstwo. Oba zdefiniowane są w kodeksie cywilnym, do którego wprowadzono je w 1990 roku. $^{2}$

Zmiany gospodarcze zachodzące od 1989 roku przeobraziły polskie rolnictwo. Rolnictwo w roku 1990 to niewielkie, słabo umaszynowione gospodarstwa, obok wielkich, niewydolnych gospodarczo państwowych gospodarstw rolnych. Dziś coraz większe znaczenie ma grupa gospodarstw silnych gospodarczo, dużych powierzchniowo, często zajmujących się wyspecjalizowaną produkcją na ogromną skalę.

Ostatni spis rolny wykazał interesujące zmiany w strukturze i wielkości produkcji gospodarstw rolnych. ${ }^{3}$ Według wyników Powszechnego Spisu Rolnego $2010^{4}$ liczba gospodarstw rolnych w czerwcu 2010 r. wynosiła 2277,6 tys. W zależności od szacunków i przyjętej terminologii około siedemset tysięcy do miliona go-

Uniwersytet w Białymstoku

Ustawa z dnia 23 kwietnia 1964 r. Kodeks cywilny (Dz.U. z 1964 r. Nr 16, poz. 93, z późn. zm.); dalej również: kc. Zgodnie z pojęciami statystyki publicznej używanymi przez rachmistrzów spisowych indywidualne gospodarstwo rolne to gospodarstwo o powierzchni użytków rolnych od 0,1 ha, będące własnością lub znajdujące się w użytkowaniu osoby fizycznej lub grupy osób oraz gospodarstwo rolne osoby nie posiadającej użytków rolnych lub posiadającej użytki rolne o powierzchni mniejszej niż 0,10 ha, która ma co najmniej: 1 sztukę bydła lub (i) 5 sztuk trzody chlewnej albo 1 lochę lub (i) 3 sztuki owiec lub (i) kóz lub (i) 1 konia lub (i) 30 sztuk drobiu lub (i) 1 strusia lub (i) 5 sztuk samic królików lub (i) 5 sztuk samic pozostałych zwierząt futerkowych lub (i) 3 sztuki pozostałych zwierząt utrzymywanych na rzeź lub (i) 1 pień pszczeli, zob. www.stat.gov.pl

4 A. Łączyński (kierownik zespołu), Powszechny spis rolny 2010. Charakterystyka gospodarstw rolnych, Warszawa 2012, s. 76 i n. (www.stat.gov.pl), zob. też W. Jagła, Wyniki Powszechnego Spisu Rolnego a zmiany w KRUS, „Ubezpieczenia w rolnictwie. Materiały i Studia” 2011, nr 42, s. 67 i n. 
spodarstw to gospodarstwa socjalne, nie mające szans na rozwój, nie dysponujące maszynami, ani środkami na inwestycje. ${ }^{5}$ Natomiast około 20 tysięcy gospodarstw w Polsce to duże jednostki wytwórcze, o produkcji przekraczającej sto tysięcy euro rocznie. $^{6}$

Wyniki powszechnego spisu rolnego potwierdziły, iż w Polsce następuje wyraźne wyodrębnienie gospodarstw silnych, nastawionych na produkcję towarową, produkujących na rynek, wciąż jednak istotne liczebnie są gospodarstwa niewielkie, nie produkujące na rynek, mające charakter socjalny.

Rzeczywistość gospodarcza przez ostatnie 25 lat zmieniła się zasadniczo. Powstała grupa gospodarstw silnych ekonomicznie, mających spore zyski, inwestujących, prowadzących rachunkowość, często mających własną markę, klientelę. Jest to grupa rosnąca liczebnie, wśród której wyróżnić należy podmioty prowadzące działalność w ramach działów specjalnych produkcji rolnej. Gospodarstwa mające po kilkaset hektarów, prowadzące intensywną produkcję rolną, wielkie fermy drobiu, czy zwierząt futerkowych, ogromne szklarnie, to rzeczywistość polskiego rolnictwa. Obok występują gospodarstwa, w których produkcja praktycznie nie jest prowadzona lub prowadzona jest w znikomym zakresie, na potrzeby własne. Tego rodzaju gospodarstwa socjalne to też istotny element polskiej wsi. Obecnie do obu kategorii, krańcowo różnych gospodarczo, stosujemy to samo pojęcie gospodarstwa rolnego. Koniecznością gospodarczą jest wyróżnienie kategorii przedsiębiorstwa rolnego i w ten sposób włączenie części rolników, zajmujących się produkcją towarową, w reguły profesjonalnego obrotu gospodarczego.

\section{Gospodarstwo rolne ujęcie ekonomiczne}

Gospodarstwo rolne to przede wszystkim zjawisko społeczne i gospodarcze. W ekonomicznej literaturze przedmiotu znajdziemy spojrzenie na gospodarstwo przede wszystkim z punktu widzenia funkcji, jakie pełni w społeczeństwie i gospodarce. Literatura ekonomiczna zawiera wiele rozważań na temat pojęcia gospodarstwa rolnego i definiuje je na różne sposoby, uwzględniając jego rolę w procesie wytwórczym w rolnictwie. Zgodnie z zawartymi tam definicjami gospodarstwo rolne to podstawowa jednostka wytwórcza w rolnictwie, która znajduje się w sferze materialnej aktywności człowieka zajmującej się produkcją żywności oraz innych produktów wytwarzanych przede wszystkim w oparciu o naturalne procesy biologiczne.

Około 950 tysięcy z istniejących w 2002 r. 2933 tys. gospodarstw, z czego 74,2\% prowadziło działalność rolniczą, a w tym 32,2\% produkowało głównie na rynek. Zob. A.P. Wiatrak Przedsiębiorstwo rolnicze - istota działania i zakres występowania, „SERiA Roczniki Naukowe” 2005, t. VII, z. 1, s. 280 i n. 
Patrząc na jednostkę produkcyjną z punktu widzenia rynkowego, dostrzegamy przemianę gospodarstwa rolnego $\mathrm{w}$ przedsiębiorstwo rolne. ${ }^{7}$ Gospodarstwo rolne to jednostka wytwórcza wewnętrznie zorganizowana, wytwarzająca produkty rolne. Każda taka jednostka produkcyjna, bez względu na jej rozmiary, jest kwalifikowana jako gospodarstwo rolne. Aby określić ją w kategorii przedsiębiorstwa, należy spojrzeć na nią z punktu widzenia powiązań z rynkiem. Za przedsiębiorstwo rolne uznać należy bowiem rolniczą jednostkę produkcyjną wytwarzającą produkty rolne na rynek. ${ }^{8}$ Dysponuje ona tymi samymi czynnikami produkcji, co w przypadku gospodarstwa rolnego, jednak decydujące tu jest nastawienie rynkowe. ${ }^{9}$ Wyróżnikiem przedsiębiorstwa jest więc towarowość produkcji, wytwarzanie nadwyżek produkcji i kierowanie ich na rynek. Przedsiębiorstwem rolnym nie będzie jednostka produkcyjna nastawiona przede wszystkim na zaspokajanie potrzeb wewnętrznych. Kryterium rynkowe nie jest w pełni ścisłe, gdyż drobne nadwyżki wytwarzane są z reguły w każdym gospodarstwie. Jednak w przypadku przedsiębiorstwa uznać należy, iż decyduje tu nastawienie na produkcję, która ma być sprzedawana. Podsumowując, uznać należy, jak podkreślał M. Urban, że każdy warsztat rolny jest gospodarstwem rolnym, ale nie musi być przedsiębiorstwem. W odwrotną stronę ta zależność nie funkcjonuje. ${ }^{10}$

Jak stwierdza A.P. Wiatrak: ,nastawienie gospodarstwa rolnego na działalność zarobkową oraz uzyskiwanie korzyści ekonomicznych i społecznych jest podstawą jego nazwania przedsiębiorstwem i to niezależnie, jak stanowi w tym zakresie

Por. też typologia gospodarstw rolnych zaproponowana przez A. Wosia (gospodarstwa naturalne i półnaturalne, drobnotowarowe, średniotowarowe (farmy rodzinne), wysokotowarowe (opierające się wyłącznie na pracy najemnej, w których gospodarstwo domowe jest całkowicie oddzielone od gospodarstwa produkcyjnego), A. Woś, Agrobiznes. Mikroekonomia, t. 2, Warszawa 1996, s. 346. Zgodzić się należy również ze zdaniem, iż "granica między nietowarowymi a towarowymi gospodarstwami rolnymi ma (...) w dużym stopniu charakter umowny. Natomiast istotne $z$ punktu widzenia ekonomicznego jest to, czy gospodarstwa mają ekonomiczne przesłanki do podejmowania inwestycji, i czy to czynią", tak W. Józwiak, A. Kagan, Gospodarstwa towarowe a gospodarstwa wielkotowarowe, „Roczniki Nauk Rolniczych, Seria G” 2008, t. 95, z. 1, s. 23.

8 Zob. W. Ziętara, Miary wielkości gospodarstw i przedsiębiorstw rolniczych, „Roczniki Nauk Rolniczych, Seria G” 2009 , z. 4, s. 269. „W przeciwieństwie do gospodarstwa przedsiębiorstwo rolnicze stanowi jednostkę gospodarczą wyodrębnioną pod względem organizacyjnym, ekonomicznym i prawnym nastawioną na wytwarzanie produktów i usług rolniczych w celu ich sprzedaży. (...) Gospodarstwa zwane indywidualnymi produkującymi na sprzedaż (towarowe) mają charakter przedsiębiorstw. Są one wyodrębnione pod względem organizacyjnym, prawnym i ekonomicznym. Funkcjonują jako samodzielne podmioty gospodarcze. Są one wpisane do gminnych rejestrów gospodarstw. Funkcjonują w formie prawnej przedsiębiorstwa osoby fizycznej, mimo że ustawa o działalności gospodarczej nie uwzględnia działalności rolniczej (...). Natomiast pozostałe jednostki, które prowadzą produkcję rolniczą na własne potrzeby są gospodarstwami z merytorycznego punktu widzenia..." Por. też A.P. Wiatrak, Przedsiębiorstwo rolnicze..., op. cit., s. 279, wskazuje, iż ekonomiści zdają sobie sprawę z tego, że definicje prawnicze mogą różnić się od ekonomicznych, natomiast z punktu widzenia ekonomii gospodarstwo nastawione na działalność zarobkową jest przedsiębiorstwem. „Nastawienie gospodarstwa rolniczego na działalność zarobkową oraz uzyskiwanie korzyści ekonomicznych i społecznych jest podstawą jego nazwania przedsiębiorstwem i to niezależnie, jak stanowi w tym zakresie ustawodawstwo prawne. Z ekonomicznego punktu widzenia wszystkie gospodarstwa rolnicze (również rodzinne) zajmujące się produkcją rolniczą przeznaczoną na sprzedaż i powiązane z rynkiem nazywamy przedsiębiorstwami”, s. 279 i n.

9 Zob. S. Prutis, Gospodarstwo rolne. Pojęcie i jego ewolucja na tle przekształceń europejskich, [w:] P. Czechowski, M. Koszycka-Iwanow, S. Prutis, A. Stelmachowski, Polskie prawo rolne na tle ustawodawstwa Unii Europejskiej, Warszawa 1997, s. 81.

10 Szerzej na ten temat M. Urban, Ekonomika i organizacja gospodarstw rolnych, Warszawa 1984, s. 87. 
ustawodawstwo prawne. Z ekonomicznego punktu widzenia wszystkie gospodarstwa rolnicze (również rodzinne) zajmujące się produkcją rolniczą przeznaczoną na sprzedaż i powiązane z rynkiem nazywamy przedsiębiorstwami." 11

Pojęciem przedsiębiorstwa rolnego posługiwać się możemy w sytuacji, gdy mamy do czynienia z rynkowo zorientowanym gospodarstwem rolnym. Pojęcie gospodarstwa rolnego jest pojęciem podstawowym, przedsiębiorstwo zaś jest jego odmianą. Obserwujemy szereg procesów różnicujących wysoko wyspecjalizowane, doskonale zorganizowane gospodarstwa rolne, działające na sposób przemysłowy, automatyzujące procesy produkcji, zatrudniające na dużą skalę siłę najemną, od małych, wykorzystujących tylko pracę własną gospodarstw, gdzie często podstawowym źródłem dochodu są płatności do gruntów. ${ }^{12}$

Z punktu widzenia ekonomii, gospodarstwo rolne nastawione na produkcję rynkową jest rodzajem przedsiębiorstwa. Do analizy funkcjonowania gospodarstw używa się tych samych narzędzi co przy analizie działalności nierolniczej. ${ }^{13} \mathrm{Za}$ ugruntowany pogląd, przyjąć należy, iż ,gospodarstwa rolnicze, jako podstawowe jednostki produkcyjne w rolnictwie prowadzące produkcję towarową mają charakter przedsiębiorstw". ${ }^{14}$

\section{Wzajemny stosunek pojęć - przedsiębiorstwo i gospodarstwo rolne w prawie polskim}

Prawidłowością polskiego ustawodawstwa jest wyraźne rozdzielenie pojęć gospodarstwa rolnego i przedsiębiorstwa. ${ }^{15} \mathrm{~W}$ rozporządzeniu Prezydenta Rzeczypospolitej z dnia 27 czerwca 1934 r. Kodeks handlowy ${ }^{16}$ pojęcia przedsiębiorstwa i gospodarstwa rolnego występują odrębnie.

Gospodarstwo rolne w ujęciu kodeksu handlowego było jednostką handlową prowadzącą działalność zmierzającą do uzyskania produktów rolnych za pomocą sił przyrody. Działalność taka była przeciwstawiona działalności handlowej - kluczo-

A.P. Wiatrak, Przedsiębiorstwo rolnicze..., op. cit., s. 279; zob. też B. Klepacki, Wybrane pojęcia z zakresu organizacji gospodarstw, produkcji i pracy w rolnictwie, Warszawa 1997, s. 9 i n.

Zob. A. Marcysiak. A. Marcysiak, Wpływ płatności bezpośrednich na dochody gospodarstwa rolniczego, „Roczniki Naukowe SERiA" 2010, t. XII, z. 3, s. 253-256, zgodnie z badaniami autorów w grupie badanej średni udział płatności bezpośrednich do gruntów w dochodzie gospodarstwa rolnych wynosił $31,7 \%$ i zwiększał się w przypadku gospodarstw mniejszych (badania obejmowały 2009 rok).

Por. A. Goliszek, Kultura organizacyjna gospodarstw rolnych. Podstawy teoretyczne, „Roczniki Naukowe SERiA” 2008, t. X, z. 3, s. 155-159.

14 Por. W. Ziętara, Tendencje i możliwości rozwoju przedsiębiorstw o różnych kierunkach produkcji, „Roczniki Naukowe SERiA" 2011, t. XIII, z. 5, s. 87.

15 Tak słusznie R. Budzinowski, Koncepcja gospodarstwa rolnego w prawie rolnym, Poznań 1992, s. 63, tak też: P. Czechowski, A. Niewiadomski, Gospodarstwo rolne jako masa majątkowa, „Studia luridica Agraria” 2009, t. VIII, s. 54.

16 Rozporządzenie Prezydenta Rzeczypospolitej z dnia 27 czerwca 1934 r. Kodeks Handlowy (Dz.U. z 1934 r. Nr 57, poz. 502 z późn. zm.). 
wemu pojęciu przy określaniu kupca (czyli przedsiębiorcy). ${ }^{17}$ Tylko niektóre gospodarstwa rolne - zgodnie z kodeksem handlowym - prowadzone w większym wymiarze mogły być wpisane do rejestru handlowego, ale ten wpis nie pozwalał na uzyskanie statusu przedsiębiorcy. ${ }^{18}$

W okresie powojennym regulacja kodeksu handlowego została utrzymana, choć jej znaczenie zdecydowanie zmalało z powodów ideologicznych. Jednak rozdział przedsiębiorstwo - gospodarstwo rolne został utrzymany, a nawet pogłębiony poprzez utożsamienie pojęcia przedsiębiorstwa z sektorem publicznym gospodarki. Jednostki państwowe, prowadzące działalność rolniczą, uzyskiwały status przedsiębiorstwa państwowego. ${ }^{19}$

Do kodeksu cywilnego pojęcia gospodarstwa rolnego i przedsiębiorstwa wprowadzono od 1 października $1990 \mathrm{r}^{20}$ Zgodnie z art. $55^{1} \mathrm{kc}$. w obecnym brzmieniu: ${ }^{21}$ „przedsiębiorstwo jest zorganizowanym zespołem składników niematerialnych i materialnych przeznaczonym do prowadzenia działalności gospodarczej. Obejmuje ono w szczególności:

1) oznaczenie indywidualizujące przedsiębiorstwo lub jego wyodrębnione części (nazwa przedsiębiorstwa);

2) własność nieruchomości lub ruchomości, w tym urządzeń, materiałów, towarów i wyrobów, oraz inne prawa rzeczowe do nieruchomości lub ruchomości;

3) prawa wynikające z umów najmu i dzierżawy nieruchomości lub ruchomości oraz prawa do korzystania z nieruchomości lub ruchomości wynikające $\mathrm{z}$ innych stosunków prawnych;

4) wierzytelności, prawa z papierów wartościowych i środki pieniężne;

5) koncesje, licencje i zezwolenia;

6) patenty i inne prawa własności przemysłowej;

7) majątkowe prawa autorskie i majątkowe prawa pokrewne;

8) tajemnice przedsiębiorstwa;

9) księgi i dokumenty związane z prowadzeniem działalności gospodarczej."

17 Zob. m.in. M. Allerhand, Kodeks handlowy. Komentarz, Lwów 1934, s. 89; podobnie S. Janczewski, Prawo handlowe, wekslowe i czekowe, Warszawa 1946, s. 31.

18 Por. D. Łobos-Kotowska, W sprawie pojęcia gospodarstwa rolnego w prawie handlowym, „Studia luridica Agraria” 2000, t. I, s. 179-180, por. też: A.W. Wiśniewski, Prawo o spółkach, t. I, Warszawa 1990, s. 102.

19 Por. S. Prutis, Pozycja prawna..., op. cit., s. 58 i n.

20 Definicje legalne pojęć przedsiębiorstwo i gospodarstwo rolne wprowadzone zostały ustawą z dnia 28 lipca 1990 r. o zmianie ustawy - Kodeks cywilny (Dz.U. z 1990 r. Nr 55, poz. 321). Definicja przedsiębiorstwa została zmieniona ustawą z dnia 14 lutego 2003 r. o zmianie ustawy - Kodeks cywilny oraz niektórych innych ustaw (Dz.U. z 2003 r. Nr 49, poz. 408) - rozszerzono ją oraz wyeliminowano pasywa.

21 W brzmieniu obowiązującym od 25 września 2003 r., na mocy ustawy z dnia 14 lutego 2003 r. o zmianie ustawy - Kodeks cywilny oraz niektórych innych ustaw (Dz.U. z 2003 r. Nr 49, poz. 408). 
Definicja gospodarstwa rolnego znajduje się w art. $55^{3}$ kc., zgodnie z którym „za gospodarstwo rolne uważa się grunty rolne wraz z gruntami leśnymi, budynkami lub ich częściami, urządzeniami i inwentarzem, jeżeli stanowią lub mogą stanowić zorganizowaną całość gospodarczą, oraz prawami związanymi z prowadzeniem gospodarstwa rolnego". ${ }^{22}$

Od czasu implementacji pojęcia gospodarstwa rolnego do kodeksu cywilnego problematyczny był wzajemny stosunek zakresu i zastosowania obu pojęć. Zasadnicze problemy wiązały się z niewymienieniem gospodarstwa rolnego $\mathrm{w}$ art. $55^{2} \mathrm{kc}$. - o czym była mowa wcześniej, oraz sformułowaniem, iż przedsiębiorstwo jest zespołem składników „służących do prowadzenia działalności gospodarczej”, przy założeniu, iż działalność rolnicza nie jest działalnością gospodarczą.

W okresie przed wprowadzeniem definicji do kodeksu cywilnego, przed przekształceniami ustrojowymi, ustawodawca podejmował próby w kierunku przekształcenia chłopskich gospodarstw rolnych w kategorię przedsiębiorstw rolnych, aż do ukształtowania przedsiębiorstwa rolnego, jako kategorii prawnej, stanowiącej odpowiednik tak określonego pojęcia ekonomicznego. ${ }^{23}$ Związane było to z założeniem, iż prawna i ekonomiczna ewolucja winna iść od gospodarstwa rolnego do przedsiębiorstwa rolnego. ${ }^{24}$ Takie konstrukcje zauważyć można w ustawodawstwie socjalistycznym. Ich przykładem może być pojęcie gospodarstwa zdolnego do towarowej produkcji oraz gospodarstwa specjalistycznego, a także rozwiązania prawne, stymulujące towarowość produkcji gospodarstw rolnych. ${ }^{25}$

Większość przedstawicieli doktryny uważa, iż „,W systemie prawa cywilnego odróżnia się przedsiębiorstwo od gospodarstwa rolnego". ${ }^{26}$ Jednocześnie, jak podkreśla P. Bielski „,istnieje (...) pogląd, że pojęcie gospodarstwa rolnego powinno się różnić od pojęcia przedsiębiorstwa w gruncie rzeczy wyłącznie przedmiotem prowadzonej, przy wykorzystaniu tego zespołu składników, działalności gospodarczej". ${ }^{27}$

Kontrowersje rodzi kwestia spojrzenia funkcjonalnego na oba pojęcia. Przedsiębiorstwo to majątek, służący do prowadzenia działalności gospodarczej. Pojawia się więc problem, czy działalność rolnicza, której służy gospodarstwo rolne, jest działalnością gospodarczą, o której mowa w art. $55^{1}$ kc. Pojawily się dwa sprzecz-

W brzmieniu obowiązującym od 25 września 2003 r. na mocy ustawy z dnia 14 lutego 2003 r. o zmianie ustawy - Kodeks cywilny oraz niektórych innych ustaw (Dz.U. z 2003 r. Nr 49, poz. 408).

Tak S. Prutis, Pozycja prawna..., op. cit., s. 58-59.

Zob. A. Stelmachowski, [w:] J. Selwa, A. Stelmachowski, Prawo rolne, Warszawa 1970, s. 28-29.

Zgodnie z § 6 rozporządzenia Rady Ministrów z 28 listopada 1964 r. w sprawie przenoszenia własności nieruchomości rolnych, znoszenia współwłasności takich nieruchomości oraz dziedziczenia gospodarstw rolnych, gospodarstwo rolne spełnia warunki do uznania go za zdolne do towarowej produkcji rolnej, jeżeli: 1) właściciel gospodarstwa nabywa grunty w celu jego powiększenia albo 2) obszar gospodarstwa nowo powstającego wynosi nie mniej niż 2 ha użytków rolnych.

P. Bielski, Spółka jawna jako forma prawna prowadzenia gospodarstwa rolnego w prawie polskim, „Prawo Spółek" 2007, nr 4, s. 38.

P. Bielski, Cele definiowania pojęcia gospodarstwa rolnego w systemie prawa - uwagi z perspektywy prawa handlowego, „Rejent” 2005, nr 10, s. 62. 
ne stanowiska, pierwsze wyraźnie odróżniające oba pojęcia, drugie akceptujące pogląd, iż działalność rolnicza jest rodzajem działalności gospodarczej.

Analizując stanowisko doktryny na temat działalności gospodarczej, nie budzi wątpliwości, iż w świetle powołanej powyżej regulacji, działalność rolnicza jest działalnością gospodarczą w rozumieniu tejże ustawy. ${ }^{28}$ Podobnie orzecznictwo wyraźnie stoi na stanowisku, iż działalność rolnicza jest działalnością gospodarczą. ${ }^{29}$

Pogląd zbliżony do regulacji kodeksu handlowego w tym przedmiocie zakłada, iż pojęcie przedsiębiorstwa i gospodarstwa rolnego są rozbieżne. „W wyniku rozwoju regulacji prawnej, nie nastąpiło wyodrębnienie przedsiębiorstwa rolnego, jako odrębnej kategorii prawa rolnego". ${ }^{30}$ S. Rudnicki stwierdza iż, ,wydaje się, że wbrew poglądom niektórych autorów istnieje zasadnicza różnica między statusem prawnym przedsiębiorstwa a gospodarstwa rolnego". ${ }^{31}$

Obecnie większość przedstawicieli doktryny przyjmuje pogląd przeciwny do rozwiązań zawartych w kodeksie handlowym, stojąc na stanowisku, iż gospodarstwo rolne jest rodzajem przedsiębiorstwa.

Tak R. Budzinowski, Status prawny rolnika jako przedsiębiorcy (zagadnienia wybrane), „Ruch Prawniczy Ekonomiczny i Socjologiczny” 2002, nr 3, s. 111 i n.; M. Sieradzka, Komentarz do art. 3 ustawy o swobodzie działalności gospodarczej, LEX 2012: „Tego rodzaju działalność jest działalnością gospodarczą w rozumieniu art. 2 ustawy o swobodzie działalności gospodarczej, jednak nie stosuje się do niej pozostałych przepisów ustawy (...) Tym samym wskazana działalność prowadzona w formie gospodarstwa rolnego jest działalnością gospodarczą, jednak jej prowadzenie zostało wyłączone spod zakresu ustawy o swobodzie działalności gospodarczej. Wskazane wyłączenie wynika ze specyfiki działalności rolniczej. Pomimo zatem, że działalność rolnicza będzie kwalifikowana jako działalność gospodarcza (oczywiście w sytuacji spełnienia cech tej działalności), a rolnicy będą uznawani za przedsiębiorców, to zarówno ta działalność, jak i podmioty je wykonujące podlegają regulacjom innych aktów prawnych. Odmienność regulacji prawnych oznacza m.in. brak obowiązku zgłoszenia, wykreślenia jej z ewidencji lub rejestru, obowiązków w zakresie kontroli." Tak również J. Ablewicz, Prawo gospodarcze publiczne, Warszawa 2010, s. 2. Tak również K. Kohutek, Komentarz do art.3 ustawy o swobodzie działalności gospodarczej LEX 2005: „Podkreślania wymaga, iż art. 3 u.s.d.g. wyłącza z zakresu stosowania ustawy wymienioną w nim działalność. Nie można na jego podstawie wnosić, iż działalność wykonywana przez rolników nie ma charakteru działalności gospodarczej w rozumieniu art. 2 u.s.d.g. i tym samym wykonujący ją rolnik nie może spełniać przesłanek podmiotowych przedsiębiorcy w rozumieniu art. 4 u.s.d.g. Działalność wytwórcza w rolnictwie - jeśli nie jest wykonywana wyłącznie dla zaspokojenia własnych potrzeb - jest zatem zarobkowa (i ukierunkowana „na zbyt”; zob. teza nr 3 komentarza do art. 2 u.s.d.g.). Ponieważ jest ona jednocześnie wykonywana w sposób zorganizowany i ciągły, jest zarazem - w ww. przypadku - działalnością gospodarczą (w rozumieniu art. 2 u.s.d.g.), a wykonujący ją rolnik (jako osoba fizyczna wykonująca tę działalność we własnym imieniu) spełnia przesłanki kwalifikowania go jako przedsiębiorcy". Tak również M. Etel, Pojęcie przedsiębiorcy, op. cit., s. $195-196$.

29 Tak Uchwała Naczelnego Sądu Administracyjnego w Warszawie w składzie 7 sędziów z dnia 2 kwietnia 2007 r., II OPS 1/07: „Prowadzenie gospodarstwa rolnego przez radnego z wykorzystaniem wydzierżawionych od gminy gruntów rolnych, będących mieniem gminy, w której radny uzyskał mandat, jest prowadzeniem działalności gospodarczej, o której mowa w art. 24f ust. 1 ustawy z dnia 8 marca 1990 r. o samorządzie gminnym (Dz.U. z 2001 r. Nr 142, poz. 1591 ze zm.)", ONSAiWSA 2007/3/62, LEX Nr 249087, zob. też wyrok Naczelnego Sądu Administracyjnego w Warszawie z dnia 29 sierpnia 2007 r., II OSK 1618/06: „Działalność wytwórcza w rolnictwie (prowadzenie gospodarstwa rolnego) jest działalnością gospodarczą w rozumieniu art. 2 ustawy $z$ dnia 2 lipca 2004 r. o swobodzie działalności gospodarczej, jednakże do tej działalności nie stosuje się pozostałych jej przepisów." LEX nr 364703, http://orzeczenia.nsa.gov.pl

30 Por. R. Budzinowski, Koncepcja gospodarstwa..., op. cit., s. 64.

31 S. Dmowski, S. Rudnicki, Komentarz do Kodeksu cywilnego, Warszawa 2011, s. 253. Por. też E. Norek, Przedsiębiorstwo w obrocie gospodarczym, Warszawa 2007, który twierdzi, iż: „z mocy art. $55^{3}$ kc przedsiębiorstwem nie jest (...) gospodarstwo rolne (...). Należy jednak uznać za przedsiębiorstwo wyodrębnione jego części położone na terenie gospodarstwa, z których prowadzona jest samodzielna działalność gospodarcza związana z produkcją rolną, np. masarnia, młyn, elewator zbożowy, gorzelnia." 
Również R. Budzinowski uważa, że „uzasadnione zatem jest twierdzenie o ewolucji konstrukcji normatywnych «od gospodarstwa rolnego do przedsiębiorstwa», aczkolwiek jest to dopiero proces w toku”, ${ }^{32}$ choć podkreśla, iż ,przedsiębiorstwo rolne różni się od innych kategorii przedsiębiorstw z uwagi na rodzaj (naturę) działalności gospodarczej, strukturę i układ dóbr instrumentalnych oraz status podmiotu." Za stanowiskiem tym opowiada się również J. Górecki, ${ }^{33}$ według którego ,zasadne jest korzystanie w odniesieniu do gospodarstwa rolnego z konstrukcji używanych dla wyjaśnienia mechanizmu rozporządzania przedsiębiorstwem."

Nie tak skrajne stanowisko zajmuje część przedstawicieli doktryny twierdząc, iż nie każde gospodarstwo rolne może być uznane za przedsiębiorstwo, ale tylko takie, które spełnia warunek prowadzenia działalności gospodarczej - czyli w takim rozumieniu towarowej działalności rolniczej nastawionej na zysk. Stanowisko to znajduje również potwierdzenie w orzecznictwie sądowym. Zgodnie z wyrokiem Sądu Apelacyjnego w Krakowie z 22 października 1993 r. ${ }^{34}$,gospodarstwo rolne może być uznane za przedsiębiorstwo lub zakład wprawiany w ruch za pomocą sił przyrody - w rozumieniu art. $435 \mathrm{kc}$. - wówczas:

- gdy przedmiot i zakres produkcji nadaje działalności rolniczej charakter działalności gospodarczej prowadzonej na własny rachunek na zasadach przedsiębiorczości, a więc powiązany w swych efektach ekonomicznych przez stosunki prawne z działalnością lub potrzebami innych podmiotów gospodarczych, oraz

- gdy samo prowadzenie danego rodzaju produkcji wytwórczej (roślinnej, zwierzęcej, ogrodniczej lub sadowniczej) oraz uzyskiwanie jej efektów, pozostaje w bezpośrednim związku ze stanem nasycenia i wykorzystania urządzeń poruszanych za pomocą sił przyrody, i to w takiej relacji, że od stopnia wykorzystania tych sił zależy w ogóle funkcjonowanie gospodarstwa w zakresie określonego rodzaju produkcji i uzyskanie jej efektów, a nie tylko ułatwienie ich osiągnięcia."

Nie każde więc gospodarstwo rolne może być przedsiębiorstwem w rozumieniu art. $435 \S 1$ kc. - może nim być tylko takie gospodarstwo rolne, które spełnia określone w tymże przepisie warunki.

Gospodarstwo rolne nastawione na zbyt jest szczególnym rodzajem gospodarstwa rolnego, które należy uznać również za przedsiębiorstwo. W podobnym kierunku wypowiedział się Trybunał Konstytucyjny w wyroku z dnia 31 stycznia

32 R. Budzinowski, Koncepcja gospodarstwa..., op. cit., s. 139-140.

33 J. Górecki, Gospodarstwo rolne jako przedmiot zastawu, „Rejent” 2003, nr 4, s. 55. Za takim stanowiskiem również J. Widło, podkreślając, iż zbędne byłoby definiowanie akurat $w$ tytule mienie gospodarstwa rolnego, gdyż nie wiadomo czemu taka definicja miałaby służyć, jeżeli gospodarstwo miałoby być jedynie zbiorem rzeczy, zob. J. Widło, Rozporządzanie przedsiębiorstwem, Kraków 2002, s. 59 i n. 
2001 r., ${ }^{35}$ stwierdzając, iż: ,prowadzenie gospodarstwa rolnego może być traktowane jako szczególny rodzaj działalności gospodarczej, a samo gospodarstwo rolne uznane być może za rodzaj przedsiębiorstwa."

To stanowisko jest najbliższe poglądom autora niniejszej pracy. Rzeczywistość gospodarcza wskazuje, iż wiele gospodarstw rolnych, spełniających warunki określone $\mathrm{w}$ art. $55^{3} \mathrm{kc}$., to małe jednostki, nastawione na produkcję zaspokajającą potrzeby własne, mające charakter socjalny. Pojęcie przedsiębiorstwa zakłada produkcję na rynek, zaś duża część polskich gospodarstw takich warunków nie spełnia. Jednocześnie trudno twierdzić, wbrew gospodarczej rzeczywistości, iż jednostka prowadząca działalność w dużej skali, za pomocą wyspecjalizowanego sprzętu, nastawiona na produkcję rynkową, nie jest przedsiębiorstwem w rozumieniu art. $55^{1}$ kc.

Innymi słowy każda działalność rolnicza prowadzona w zorganizowanej formie na gruncie i składająca się z określonych składników majątkowych będzie gospodarstwem rolnym, jednak nie każde gospodarstwo będzie przedsiębiorstwem. Wyraźnie należy odróżnić gospodarstwa małe, nastawione na produkcję zaspokajającą własne potrzeby rolnika, od gospodarstw produkujących na rynek.

Podmiot prowadzący ,zarobkową działalność wytwórczą, budowlaną, handlową, usługową oraz poszukiwanie, rozpoznawanie i wydobywanie kopalin ze złóż, a także działalność zawodową, wykonywaną w sposób zorganizowany i ciągły," w tym działalność rolniczą, wykonuje taką działalność w ramach zorganizowanej całości gospodarczej określanej mianem przedsiębiorstwa. Działalność gospodarcza wykonywana w ramach gospodarstwa rolnego kwalifikuje to gospodarstwo do pojęcia przedsiębiorstwa.

\section{Pojęcie przedsiębiorstwa rolnego}

Mają rację P. Czechowski i A. Niewiadomski, iż w Polsce większość gospodarstw rolnych nie jest gospodarstwami towarowymi i, jako takie, nie mogłyby spełniać definicji normatywnej przedsiębiorstwa zawartej w kodeksie cywilnym. ${ }^{36}$ Zgodzić się należy również ze zdaniem I. Augustyńskiej-Grzymek, iż ze względu na rozmiar, większość gospodarstw nie posiada składników wyliczonych w art. $55^{1}$ kc. Brak jest zwykle oznaczeń indywidualizujących je w obrocie, nie prowadzi się w nim rachunkowości rolnej, gospodarstwo nie posiada zarejestrowanych patentów, wzorów użytkowych, czy zdobniczych. ${ }^{37}$ Jednocześnie pamiętać trzeba o dużej licz-

35 Wyrok Trybunału Konstytucyjnego z dnia 31 stycznia 2001 r., sygn. akt P 4/99, (Dz.U. z 2001 r. Nr 11, poz. 91), z uzasadnienia.

36 P. Czechowski, A. Niewiadomski, Gospodarstwo rolne..., op. cit., s. 57.

37 „Większość gospodarstw w Polsce to gospodarstwa niewielkie, dla których wyliczenie z art. $55^{1}$ kc jest zupełnie nieadekwatne. Z danych Głównego Urzędu Statystycznego wynika, że 56,6\% gospodarstw indywidualnych to gospodarstwa o powierzchni $1-10$ ha, w tym w grupie gospodarstw $1-5$ ha, $75 \%$ produkuje wyłącznie lub 
bie gospodarstw, które takie warunki spełniają. W nauce ekonomii nie ma wątpliwości, iż do towarowego gospodarstwa rolnego należy stosować kategorię przedsiębiorstwa. Pojęcie wartości niematerialnych i prawnych, znaków towarowych, pozycji na rynku, klienteli - kategorie te stworzone na użytek przedsiębiorstw, jak najbardziej mają zastosowanie do podmiotów prowadzących towarową produkcję rolną. Wymogi współczesnej gospodarki nie pozostawiają wątpliwości - w przypadku towarowych gospodarstw rolnych, koniecznością jest stosowanie do nich regulacji dotyczących przedsiębiorstw.

Jednak zauważyć należy, iż coraz częściej w rzeczywistości gospodarczej Polski pojawiają się takie firmy, jak na przykład Top Farms Głubczyce, dysponujące powierzchnią 11 tysięcy hektarów, otrzymujących płatności bezpośrednie do gruntów w wysokości $10.800 .010 \mathrm{zl}$ - produkujące 40 tys. ton zbóż, 6 tys. ton rzepaku, 2400 krów, ${ }^{38}$ zatrudniająca łącznie prawie 700 osób. Do takich organizmów gospodarczych stosujemy podobne rozwiązania prawne jak do 1,5-hektarowego gospodarstwa produkującego niewielką ilość żywności na potrzeby jego właściciela.

Skala działalności gospodarstw rolnych również nie jest mniejsza niż przedsiębiorstw. Biorąc pod uwagę tylko działy specjalne produkcji rolnej, co najmniej kilka tysięcy osób prowadzących taką działalność przekroczyło próg 1.200.000 euro obrotu rocznie. Jest to z pewnością produkcja towarowa. Jednostka organizacyjna, w której taka produkcja się odbywa, posiada wszystkie elementy wymienione w art. $55^{3}$ jako składniki przedsiębiorstwa. Analizując dane dotyczące produkcji w gospodarstwach rolnych, I. Augustyńska-Grzymek zauważa, iż mniejsze gospodarstwa rolne nastawione są głównie na samozaopatrzenie i nie produkują na rynek, i stwierdza, iż ,przedstawione dane statystyczne, pozwalają na zastosowanie pojęcia przedsiębiorstwa, wyłącznie do gospodarstw dużych, zajmujących się nie tylko produkcją rolniczą, ale również przetwórstwem rolno-spożywczym. Należy więc przyjąć, że możliwe jest uznanie gospodarstwa rolnego za szczególny rodzaj przedsiębiorstwa, który wyróżnia się ze względu na prowadzoną działalność rolniczą, ale tylko wówczas, gdy to gospodarstwo rolne odpowiada cechom przedsiębiorstwa $\mathrm{z}$ art. $55^{1} \mathrm{kc} "{ }^{39}$ Analiza powyższa pokrywa się ze zdaniem autora, iż tylko niektóre, towarowo nastawione gospodarstwa rolne będą mogły być uznane za przedsiębiorstwa.

głównie na potrzeby własne, a dodatkowo 3,8\% gospodarstw nie prowadzi stale lub okresowo w ogóle działalności rolniczej. Ponad 55\% gospodarstw prowadzących działalność, głównie na potrzeby własne i przeznaczających tylko nadwyżki na sprzedaż (średnioroczna wartość sprzedaży około 1,5 tyś zł) ma powierzchnię około 3 ha. Wielkości te są tylko nieco większe, przy uwzględnieniu danych statystycznych Instytutu Ekonomiki Rolnictwa i Gospodarki Żywnościowej. Badane gospodarstwo posiadało średnio 13,90 ha użytków rolnych. Zaś wartość produkcji towarowej na 1 ha użytków rolnych wynosiła 2 634,40 zł." A. Skarżyńska, I. Augustyńska-Grzymek, Koszty jednostkowe i dochodowość produkcji rolniczej w gospodarstwach indywidualnych w 1998 roku, Warszawa 1999, s. 41. Badania robione były ponad 10 lat temu, ale są w dużej części nadal aktualne. 
Obecnie kryteria gospodarstwa rolnego, według kodeksu cywilnego, spełnia zarówno grunt rolny o powierzchni 1 ha użytków rolnych, który pełni rolę ogródka przydomowego wraz z zagonem warzyw i kilkunastoma kurami, jak i grunt rolny o powierzchni 700 ha z maszynami i zabudowaniami wartymi kilkadziesiąt milionów złotych.

Oba te organizmy gospodarcze w sposób istotny różnią się od siebie, zupełnie inaczej funkcjonują na rynku. Stworzenie kategorii przedsiębiorstwa rolnego - które od przedsiębiorstwa w rozumieniu art. $55^{1} \mathrm{kc}$. różniłoby się tylko przedmiotem działalności, oderwanie pojęcia przedsiębiorstwa rolnego od ziemi, odróżnienie przedsiębiorstwa rolnego od gospodarstwa poprzez określenie skali produkcji przeznaczonej na zbyt - jest konieczne, aby uporządkować regulację dotyczącą jednostek rolnych. Definicja gospodarstwa rolnego zawarta w kodeksie cywilnym pochodzi z 1964 roku $^{40}$ i zdecydowanie nie przystaje do współczesnego obrotu gospodarczego.

Systematyzując powody, dla których należy wprowadzić pojęcie przedsiębiorstwa rolnego do prawa polskiego należy podnieść, co następuje.

\section{A. Wyjaśnienie wątpliwości co do stosowania art. $5^{2}$ kc. do obrotu jednostkami produkcyjnymi $w$ rolnictwie}

Przede wszystkim, powinno nie być wątpliwości co do możliwości obrotu całościami gospodarczymi, tj. dokonywania czynności prawnych mających za przedmiot określony i zorganizowany zespół składników, służący do prowadzenia danego typu działalności. Obecny stan prawny w tym zakresie daleki jest od precyzji, budzi spory w doktrynie $\mathrm{i}$ w orzecznictwie. W przypadku profesjonalnego obrotu gospodarczego nie należy zdawać się na orzecznictwo. Regulacje prawne dotyczące gospodarstw rolnych wyraźnie powinny wskazywać na rozwiązania, takie jak w art. $55^{2} \mathrm{kc}$. Ani doktryna, ani orzecznictwo nie powinny rozstrzygać, czy w skład gospodarstwa rolnego w rozumieniu art. $55^{3} \mathrm{kc}$ wchodzi prawo do znaku towarowego sera produkowanego $\mathrm{w}$ gospodarstwie rolnym albo prawa autorskie do treści i układu strony internetowej gospodarstwa i czy te prawa przechodzą wraz z gospodarstwem rolnym. Wprowadzenie pojęcia przedsiębiorstwa rolnego powinno łączyć się z wyraźnym objęciem obrotu taką jednostką regulacją art. $55^{2} \mathrm{kc}$. powtórzeniem definicji z rozporządzenia w sprawie przenoszenia własności nieruchomości rolnych, znoszenia współwłasności takich nieruchomości oraz dziedziczenia gospodarstw rolnych z 28 listopada 1964 r., tylko w rozporządzeniu grunty musiały być własnością tego samego podmiotu. 


\section{B. Procedury upadłościowe i naprawcze}

Zgodnie z art. 5 ust. 1 ustawy Prawo upadłościowe i naprawcze ${ }^{41}$,przepisy ustawy stosuje się do przedsiębiorców w rozumieniu ustawy z dnia 23 kwietnia 1964 r. - Kodeks cywilny (Dz.U. Nr 16, poz. 93, z późn. zm.), jeżeli ustawa nie stanowi inaczej”. Ponadto w myśl art. 6 pkt 5 powołanej ustawy „nie można ogłosić upadłości osób fizycznych prowadzących gospodarstwo rolne".

Pojęcie przedsiębiorstwa rolnego umożliwia odniesienie się do pojęcia przedsiębiorcy, a co za tym idzie uczestnictwo w regulacjach prawnych przeznaczonych dla profesjonalnego obrotu. ${ }^{42}$ Przede wszystkim chodzi o możliwość poddania się procedurom upadłościowym oraz postępowaniu naprawczemu. W obecnym stanie prawnym tego rodzaju rozwiązanie nie jest możliwe. Rolnik może skorzystać wyłącznie z regulacji dotyczącej upadłości konsumenckiej (art. 491 ${ }^{1}$ i następne prawa upadłościowego i naprawczego). Jednak upadłość konsumencka jest instytucją praktycznie niestosowaną, ze względu na nieżyciowe i bardzo niekorzystne rozwiązania dla osób chcących z niej skorzystać. ${ }^{43}$

\section{Obowiązki rejestracyjne - księgowość (uproszczona)}

Stosownie do art. 3 ustawy o swobodzie działalności gospodarczejej „przepisów ustawy nie stosuje się do działalności wytwórczej w rolnictwie w zakresie upraw rolnych oraz chowu i hodowli zwierząt, ogrodnictwa, warzywnictwa, leśnictwa i rybactwa śródlądowego, a także wynajmowania przez rolników pokoi, sprzedaży posiłków domowych i świadczenia w gospodarstwach rolnych innych usług związanych z pobytem turystów oraz wyrobu wina przez producentów będących rolnikami wyrabiającymi mniej niż 100 hektolitrów wina w ciągu roku gospodarczego, o których mowa w art. 17 ust. 3 ustawy z dnia 12 maja 2011 r. o wyrobie i rozlewie wyrobów winiarskich, obrocie tymi wyrobami i organizacji rynku wina (Dz.U. Nr 120, poz. 690 i Nr 171, poz. 1016)."

Wyłączenie rolników z profesjonalnego obrotu gospodarczego ma za zadanie ułatwienie im funkcjonowania w codziennej działalności. Szczególnie w przypadku gospodarstw socjalnych brak jest powodów, które uzasadniałyby konieczność poddawania takich organizmów gospodarczych procedurze rejestracji, obowiązkowi zakładania konta bankowego itd. W obecnym stanie prawnym rolnicy nie są zobowiązani do prowadzenia rachunkowości w jakiejkolwiek formie, nie mają obowiązku sporządzać żadnej ewidencji podatkowej. Podstawowe obciążenie podatkowe w rol-

Ustawa z dnia 28 lutego 2003 r. Prawo upadłościowe i naprawcze (t.j. Dz.U. z 2012 r., poz. 1112 z późn. zm.). Szerzej P. Bielski, Cele definiowania pojęcia..., op. cit., s. 64 i n. też na temat różnic między przedsiębiorstwem a gospodarstwem rolnym w krajach Europy Zachodniej, A. Lichorowicz, Gospodarstwo rolne..., op. cit., s. 15. „Instytucja upadłości konsumenckiej obecnie funkcjonująca w Polsce jest martwa. Kilkanaście ogłoszonych upadłości dobitnie to potwierdza", P. Bieżuński, Początki upadłości konsumenckiej LEX nr 130771.

Ustawa z dnia 2 lipca 2004 r. o swobodzie działalności gospodarczej (t.j. Dz.U. z 2013 r., poz. 372 z późn. zm.). 
nictwie - podatek rolny - określany jest poprzez wymiar użytków rolnych wyrażonych w hektarach przeliczeniowych i również nie wymaga prowadzenia żadnej ewidencji dotyczącej wyników finansowych, sprzedaży itd.

Od pewnego poziomu wielkości jednostki wytwórczej, wyłączenie jej z określonych rygorów wydaje się nieuzasadnione. Duże jednostki gospodarcze mające przychody liczone w milionach euro pozostają poza obowiązkową księgowością. W takich jednostkach księgowość jest często prowadzona na potrzeby własne, chociażby ze względu na wymagania związane ze współpracą z bankami, uzyskiwaniem kredytów itd. Jednak od pewnej wielkości jednostki prowadzenie urządzeń księgowych powinno być obligatoryjne ze względu na wymogi rynkowe, wymogi prawa bankowego, prawa upadłościowego. Jeżeli dopuścilibyśmy rolników do regulacji upadłościowych, prowadzenie przynajmniej uproszczonej księgowości jest konieczne chociażby ze względu na wymagania postępowania upadłościowego i naprawczego, gdzie nieuniknione jest oparcie decyzji sądu na wynikach finansowych danej jednostki gospodarczej.

Pojęcie przedsiębiorstwa rolnego obejmujące jednostki produkcyjne od określonego poziomu produkcji (sprzedaży) byłoby jednocześnie punktem wyjścia do określenia wielkości jednostki mającej obowiązek prowadzenia uproszczonej księgowości. Co do pełnej księgowości wystarczy w tym zakresie regulacja ustawy z 29 września 1994 r. o rachunkowości, ${ }^{45}$ zgodnie z którą obowiązek prowadzenia pełnej księgowości dotyczy m.in. (art. 2 ust. 1 pkt 2) osób fizycznych, spółek cywilnych osób fizycznych, spółek jawnych osób fizycznych, spółek partnerskich oraz spółdzielni socjalnych, jeżeli ich przychody netto ze sprzedaży towarów, produktów i operacji finansowych za poprzedni rok obrotowy wyniosły co najmniej równowartość w walucie polskiej 1.200.000 euro. Zgodnie z art. 24a ust. 2 ustawy o podatku dochodowym od osób fizycznych obowiązek prowadzenia księgi dotyczy również osób prowadzących działy specjalne produkcji rolnej, ale wyłącznie wtedy, gdy osoby te zgłosiły zamiar prowadzenia tych ksiąg, czyli rezygnują z możliwości rozliczania podatku według szacunkowych norm dochodu.

\section{Punkt wyjścia do koniecznej reformy podatkowej i w zakresie ubezpieczeń społecznych i zdrowotnych}

Pojęcie przedsiębiorstwa rolnego powinno być punktem wyjścia do reformy systemu podatkowego oraz systemu ubezpieczeń społecznych i zdrowotnych w rolnictwie. Twierdzenie, iż małe, socjalne, samozaopatrzeniowe gospodarstwa rolne nie zniosą zwiększenia obciążeń finansowych jest słuszne. W Polsce istnieje kilkaset tysięcy jednostek organizacyjnych służących głównie zaspokajaniu potrzeb żywnościowych osób je prowadzących. Z drugiej strony, istnieją jednostki gospo-

T.j. Dz.U. Nr 330 z 2013 r. z późn. zm. 
darcze doskonale dające sobie radę na rynku, które wymagają uznania ich za pełnoprawnych uczestników obrotu gospodarczego. Prawo winno taką sytuację dostrzec i uregulować. Przedsiębiorstwa rolne powinny być poddane rygorom podobnym do rygorów obowiązujących przedsiębiorców. Takie jednostki powinny być opodatkowane również jak przedsiębiorcy w innych dziedzinach. Można wprowadzić różne mechanizmy opodatkowania ryczałtowego, jednak mechanizm powinien być wspólny dla przedsiębiorców i przedsiębiorców rolnych - podatek dochodowy i składki na ubezpieczenia społeczne i zdrowotne na takich samych zasadach.

Uznanie, iż istotą pojęcia gospodarstwa rolnego jest działalność rolnicza pozwoli zaliczyć do tej szerokiej kategorii zarówno gospodarstwa socjalne, jak i przedsiębiorstwa rolne. Stworzenie kategorii przedsiębiorstwa rolnego pozwoli na rozszerzenie obrotu profesjonalnego na podmioty działające na rynku i objęcie tych podmiotów nowymi regulacjami w zakresie podatkowym i ubezpieczeniowym.

\section{Wnioski}

Jak zauważa R. Budzinowski ${ }^{46}$ „kategoria przedsiębiorstwa zajęła w nowym prawie prywatnym pozycję centralną". Przyjąć należy, iż pojęcie przedsiębiorstwa rolnego jako jednostki produkcyjnej - winno być fundamentem polityki rolnej. W gospodarce planowej twierdzenie, iż przedsiębiorstwo rolne nie jest kategorią obowiązującego prawa rolnego było uzasadnione. ${ }^{47} \mathrm{~W}$ dzisiejszych warunkach gospodarki rynkowej to właśnie pojęcie przedsiębiorstwa rolnego winno wychodzić na pierwszy plan.

W obecnym stanie prawnym pojawia się szereg wątpliwości co do stosowania przepisów dotyczących przedsiębiorstwa do gospodarstwa rolnego. Należy te wątpliwości rozwiązać, poprzez wyraźne wskazanie, iż do gospodarstw towarowych (przedsiębiorstw rolnych) stosujemy przepisy dotyczące przedsiębiorstw. Prawo cywilne jest dziedziną, gdzie zmiany winny być dokonywane powoli i szczególnie ostrożnie. Jednak należy zaproponować zmiany de lege ferenda zmierzające do określenia miejsca gospodarstw towarowych w systemie prawnym. Zmiana mogłaby polegać na dodaniu art. $55^{5} \mathrm{kc}$. zawierającego definicję przedsiębiorstwa rolnego. Proponowane brzmienie art. $55^{5} \mathrm{kc}$. to:

„Przedsiębiorstwo rolne jest zorganizowanym zespołem składników materialnych i niematerialnych przeznaczonych do prowadzenia rolniczej działalności gospodarczej. Do przedsiębiorstwa rolnego stosuje się odpowiednio przepisy dotyczące przedsiębiorstwa i gospodarstwa rolnego." 
Zmiana taka w minimalny sposób ingerowałaby w treść kodeksu, jednocześnie pozwalałaby objąć regulacją kodeksową w sposób wyraźny jednostki gospodarcze, prowadzące towarową produkcję rolną, w tym produkcję nie opartą na gruntach rolnych. Pamiętać należy, iż definicja gospodarstwa rolnego zawarta w art. $55^{3} \mathrm{kc}$. obejmuje dwa różne pojęcia - socjalne gospodarstwo rolne oraz gospodarstwo produkujące na rynek.

Punktem wyjścia reformy polskiego rolnictwa powinno być pojęcie przedsiębiorstwa rolnego. Gospodarstwo rolne określonej wielkości, produkujące na rynek, powinno być objęte regułami gospodarki rynkowej. Odpowiednio wysoki próg wielkości produkcji (na przykład 100.000 euro rocznie) pozwoli na wyodrębnienie jednostek, które rzeczywiście zajmują się produkcją rynkową. Prowadzenie rachunkowości, możliwość korzystania z instytucji upadłości, określone wymagania rejestracyjne nie utrudnią działalności takim organizmom gospodarczym. Jednocześnie przedsiębiorstwo rolne powinno być objęte rozwiązaniami w zakresie podatku dochodowego oraz ubezpieczeń społecznych i zdrowotnych podobnymi do rozwiązań dotyczących przedsiębiorców. 
ABOUT THE NECESSITY OF INTRODUCTION INTO THE POLISH LAW SYSTEM OF THE NOTION AGRICULTURAL FIRM

Key words: agricultural farm, company, organized economic entity

In Polish law there are two notions pertaining to organized economic entities - a company and an agricultural farm. The phrase agricultural farm refers to all production units based on the cultivation of agricultural land with the use of biological processes. The change of the political system and economic reforms that followed it, facilitated creation of agricultural farms of an intensive character. They are treated by the lawgiver in the same way as social farms, which do not sell their products.

The author of this article aims to prove that it is indispensable to introduce into the Polish law a new notion naming an agricultural unit producing commodities for sale. Such production units should be treated in the same way as companies - they should keep their accounts, have the possibility to use the bankruptcy procedure, etc. Eventually, such a notion could give origin to a reform in agriculture concerning the tax system, social security and health system. The new notion could be treated as the first step towards this end. 